Пименов С.В. Анализ финансово-экономических показателей нефтедобывающих и нефтеперерабатывающих предприятий РФ

УДК 336025

DOI: $10.21779 / 2500-1930-2017-32-4-92-96$

\title{
С.В. Пименов
}

\section{Анализ финансово-экономических показателей нефтедобывающих и нефтеперерабатывающих предприятий $\mathbf{P \Phi}^{1}$}

Высшая школа бизнеса Южного федерального университета; Россия, 344019, г. Ростов-на-Дону, ул. 23-я линия, 43; gartemen@mail.ru

Статья посвящена анализу основных финансово-экономических показателей деятельности предприятий нефтяного комплекса. С учетом того что предприятия нефтегазового сектора являются основными поставщиками налоговых доходов в бюджет России, тема весьма актуальна.

Рассмотрены динамика показателей добычи и переработки нефти, проблемы и перспективы нефтедобывающих и нефтеперерабатывающих компаний, основные тенденции, складывающиеся в нефтедобыче и нефтепереработке, и результаты, к которым они привели. Проанализировано, как отразилась непростая рыночная ситуация (рост курса доллара, увеличение ставки налога на добычу полезных ископаемых (НДПИ), снижение цен на нефть) на финансовом состоянии предприятий нефтедобычи и нефтепереработки. Приведено авторское мнение о ближайших планах реформирования системы налогообложения нефтедобывающих и нефтеперерабатывающих предприятий (изменение формулы расчета НДПИ, введение налога на дополнительный доход (НДД)).

Ключевые слова: нефть, нефтепродукты, налог на добычу полезных ископаемых, налоговый маневр.

Основными отраслевыми показателями, характеризующими состояние добывающего сектора нефтяной отрасли как экспортноориентированной, являются цена на нефть и курс доллара США, исходя из которых определяются размер НДПИ и таможенной пошлины, а также объемы реализации нефти и нефтепродуктов как на внешнем, так и на внутреннем рынке.

За 2015 год мировые цены на нефть в среднем снизились на 47,8 \% по сравнению с прошлым годом. При этом в отчетном периоде прослеживается колебание средних мировых цен на нефть (минимальное значение - 36,24 дол./бар. в декабре 2015 года, максимальное - 63,07 дол./бар. в мае 2016 г.).

Мировые и внутренние рыночные цены на нефтепродукты в первую очередь обусловлены мировым уровнем цен на нефть, уровнем спроса и предложения на рынке нефтепродуктов и уровнем конкуренции на различных рынках. При этом динамика цен на разные нефтепродукты различна. Кроме того, уровень мировых цен определяют прогнозы крупнейших ценовых агентств.

Динамика макроэкономических показателей (курс доллара США и цена на нефть), оказывающих определяющее воздействие на финансовые и налоговые показатели нефтяной отрасли за 2015 год по сравнению с аналогичным периодом прошлого года,

\footnotetext{
${ }^{1}$ Статья подготовлена по материалам доклада, представленного на III Международной научнопрактической конференции «Модернизация экономических систем: опыт и перспективы», которая прошла 27-28 апреля 2017 года в Дагестанском государственном университете (г. Махачкала, РФ).
}

92

Вестник Дагестанского государственного университета.

Серия 3. Общественные науки. 2017. Том 32. Вып. 4 
Пименов С.В. Анализ финансово-экономических показателей нефтедобывающих и нефтеперерабатывающих предприятий РФ

отражена на рисунке 1.

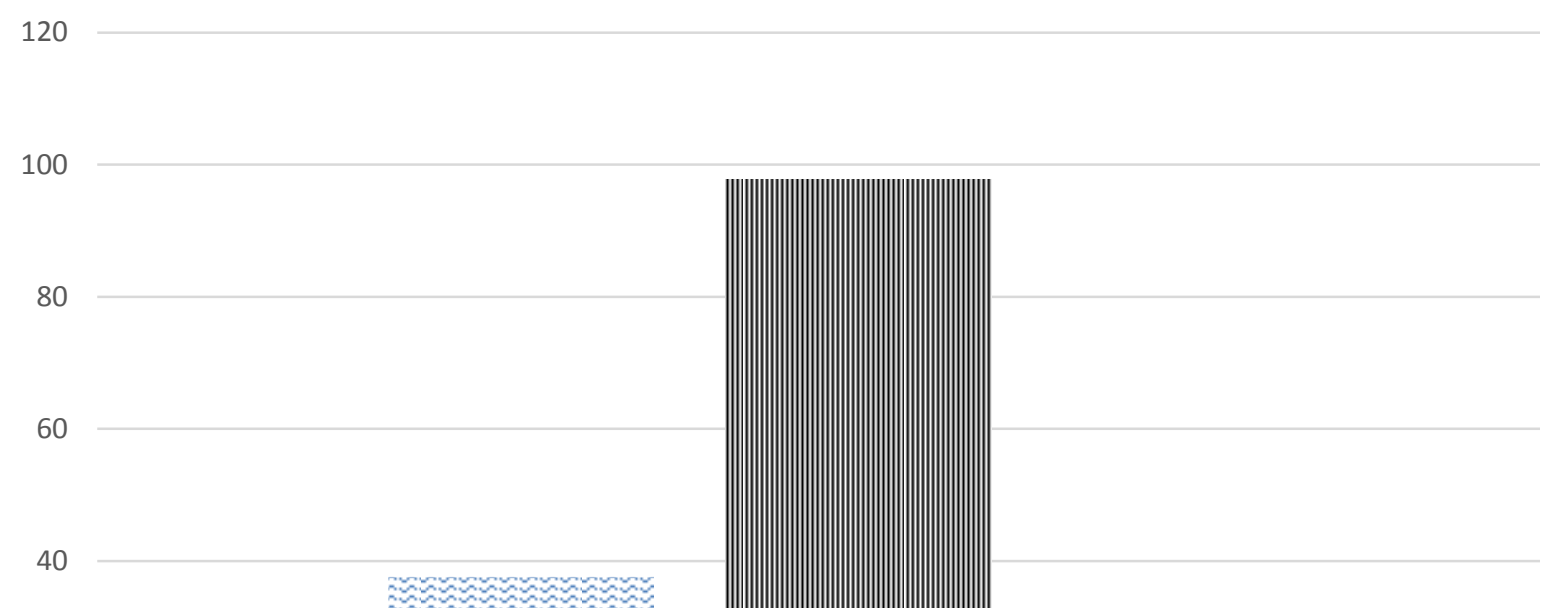

Рис. 1. Динамика средней цены на нефть и курса доллара США к рублю в 2014-2015 гг.

Падение средней цены на нефть сорта Urals составило 46,7 долл./бар. или 48,5 \% (с 97,7 дол./бар., за 2014 г. до 51,0 дол./бар. за 2015 г.) при росте среднего курса доллара на 23,4 руб./дол. или на 67,6 \% (с 37,6 руб./дол. за 2014 г. до 61,0 руб./дол. за 2015 г.). При этом в отчетном периоде по сравнению с прошлым годом наблюдалось отставание роста курсов иностранных валют (на 23,4 дол./руб. или в 1,6 раза) от падения цены на нефть (на 46,7 дол./бар. или в 1,9 раза) в абсолютном выражении $[1,8]$.

За 2015 год наблюдалась тенденция изменения ежемесячного среднего курса доллара США в сторону роста на 67,6 \% по сравнению с аналогичным периодом прошлого года (с 37,6 до 61,0 руб./дол.). Так, средний курс доллара США достигал своего максимума в 69,68 руб. за долл. в декабре 2015 года и минимума в 50,59 руб. за долл. в мае [2, с. 152]. Тогда как в аналогичном периоде 2014 года максимальное значение курса доллара составляло 55,54 руб./дол. и минимальное - 33,46 руб./дол.

Одновременно в отчетном периоде 2015 года наблюдается увеличение расчетной ставки НДПИ на 8,5 \% (с 5 830,9 руб./т до 6326,4 руб./т) и снижение ставок таможенных пошлин на 67,2 \% (с 366,66 до 120,25 дол./т). Рост расчетной ставки НДПИ на фоне снижения таможенной пошлины в связи с введением «налогового маневра» и роста среднего курса доллара США за 2015 год относительно аналогичного показателя 2014 года привели к росту средней чистой экспортной выручки (данный показатель равен стоимости тонны нефти за минусом таможенной пошлины и ставки НДПИ) администрируемых компаний на 25,2 \% (с 7039,09 до 8 812,74 руб./т).

Следует отметить, что одним из основных показателей, влияющих на экономическую ситуацию в нефтяной отрасли, является баланс спроса и предложения нефти на мировом рынке.

В отчетном периоде наблюдается рост объемов экспорта нефти (+21 млн т) и нефтепродуктов (+7 млн т) по сравнению с прошлым годом на фоне роста чистой экспортной стоимости нефти.

Рост объемов экспорта нефти и нефтепродуктов обусловлен развитием экспортного направления поставок в страны дальнего зарубежья (по нефти: на 23 млн т, или на 11,6 \%, по нефтепродуктам: на 8 млн т, или на 5,2 \%) [3, с. 39]. При этом добыча нефти по России и поставка нефти на переработку на российские НПЗ снизились на 0,2 и 2,5 \% соответственно (2015 год: добыча - 440,6 млн т, поставка на переработку - 282,0 
Пименов С.В. Анализ финансово-экономических показателей нефтедобывающих и нефтеперерабатывающих предприятий РФ

млн т; 2014 год: добыча - 441,7 млн т, поставка на переработку - 289,1 млн т).

За 2015 год объем добычи нефти на территории РФ составил 440,6 млн т, что на $0,2 \%$ меньше, чем за аналогичный период 2014 года [4, с. 42].

Прирост добычи нефти за 2015 г. наблюдается по холдингам: Татнефть - на 0,7 млн т, Сургутнефтегаз - на 0,2 млн т и Башнефть - на 0,1 млн т.

Прирост объемов добычи нефти достигается только за счет разработки, освоения новых месторождений, их развития и внедрения новых методов бурения.

Наибольший прирост добычи пришелся на Восточную Сибирь, где были введены в эксплуатацию такие крупные месторождения, как Северо-Талаканское и Алинское в Якутии (Сургутнефтегаз), Ошское, Инзырейское, Тобытское месторождения (ООО «ЛукойлКоми»), находящиеся на территории Ненецкого и Ямало-Ненецкого автономного округов, а также шельфовые месторождения Охотского моря (Роснефть) и др.

На сегодня в России действуют 28 крупных нефтеперерабатывающих заводов (НПЗ), обеспечивающих до 98 \% переработки нефти. На мини-НПЗ перерабатывается $2 \%$ нефти [5, с. 100].

С 1 января 2015 г. Правительством РФ были снижены налоговые ставки акцизов на автомобильный бензин, дизельное топливо в среднем на $32,2 \%$. При этом наибольшее снижение ставки акцизов произошло по классам дизтоплива в среднем на 40,2 \% [1, c. 12].

Объемы первичной переработки нефти по России за 2015 год составили 282 млн т, снизившись на 7,1 млн т, или на 2,5 \% относительно аналогичного периода прошлого года (2014 год - 289,1 млн т).

При этом наблюдается снижение объемов переработки нефти на 11 млн т, или на 5 \%, которое приходится на НПЗ, входящие в состав таких Холдингов, как Роснефть, Лукойл, Башнефть.

Одновременно с общим незначительным снижением объемов нефти, переданных на переработку в целом по России в отчетном периоде (на 7,1 млн т, или на 2,5 \%) наблюдается снижение данного показателя на 5,1 млн т, или на 11,3 \%, что обусловлено тенденцией роста реализации нефти на экспорт на 21,5 млн т, или на 9,6 \% (в т. ч. в дальнее зарубежье на 22,6 млн т, или на 11,4 \%) [6, с. 21].

За 2015 год наблюдается следующая динамика производства основных видов нефтепродуктов относительно прошлогодних объемов: рост объемов выработки автобензина - на 4,8 \%; уменьшение объемов выработки: дизтоплива - на 2,0 \%, мазута топочного на - 9,3 \%, авиакеросина - на 7,9 \% [8, с. 62].

При этом в целом наблюдается незначительное снижение первичной переработки нефти за 2015 год по сравнению с аналогичным периодом 2014 года.

В течение 2013 года увеличилось число интернациональных альянсов, которые в дальнейшем планируют свою работу по сложным, но перспективным схемам. В число таких стратегических слияний входит покупка Китайской национальной нефтяной корпорацией доли в «Ямале СПГ», создание «Роснефтью» нового предприятия совместно с ExxonMobil и Eni для разработки месторождений в условиях Крайнего Севера, в частности в Арктике [7, с. 105].

По причине увеличения расходов и налогового бремени крупные российские компании будут пытаться оптимизировать свои бизнес-портфели, распродавая непрофильные активы, не доказавшие свою перспективность. В течение нескольких последующих лет, возможно, сложится благоприятная ситуация для консолидации небольших активов в руках нескольких гигантов нефтегазовой отрасли. 
Пименов С.В. Анализ финансово-экономических показателей нефтедобывающих и нефтеперерабатывающих предприятий РФ

С 2018 года в России будет запущена новая система налогообложения нефтяной отрасли - в пилотном режиме вводится налог на добавленный доход (НДД) при одновременном снижении НДПИ и таможенной пошлины. Как считают эксперты, реформа подстегнет нефтяные компании к более эффективной разработке зрелых месторождений, но, по мнению автора, в краткосрочной перспективе эти действия только осложнят налоговое администрирование нефтедобывающих и нефтеперерабатывающих предприятий.

\section{Литература}

1. Артеменко Д.А., Овчар О.В. Разработка мер налогового стимулирования развития нефтяных кластеров как институциональной основы преодоления зависимости экономики от экспорта сырой нефти // Налоги и налогообложение. - 2017. - № 3. C. 1-17.

2. Надырова Г.Р. Влияние уровня налоговой нагрузки на эффективность компании в нефтяной отрасли по странам (в России, Канаде, Мексике, США и Норвегии) // Новая наука: современное состояние и пути развития. - 2016. - № 5-1. - С. 150-154.

3. Любавский С.Л. Налогообложение ресурсов с изменяющейся доходностью // Налоговая политика и практика. - 2011. - № 2. - С. 38-45.

4. Хорохорин A.E. Стратегия развития современных нефтехимических комплексов, мировой опыт и возможности для России. - М.: Российский государственный университет нефти и газа им. И.М. Губкина, 2015. - 178 с.

5. Виноградова A.B. Институциональный механизм диффузии природной ренты и его особенности в нефтегазовом комплексе России // Журнал институциональных исследований. - 2011. - Т. 3, № 2. - С. 98-103.

6. Крюков В.А., Токарев А.Н., Шмат В.В. Возможности роста на основе нефтегазового сектора // Налоги. Инвестиции. Капитал. - 2014. - № 4. - С. 18-25.

7. Понкратов B.B. Налогообложение добычи нефти в России: в ожидании налогового маневра // Налоги. Инвестиции. Капитал. - 2014. - № 4. - С. 101-118.

8. Высоикий В.И., Фельдман С.Л. Нефтегазовая промышленность мира: справочно-информационный обзор. - М.: ОАО «ВНИИзарубежнефтегаз», 2016. - 98 с.

9. Павлова Л.П. Совершенствование НДПИ по нефти // Финансы. - 2008. № 6. - C. 37-40.

10. Пансков В.Г. О налоговом стимулировании инвестиционной деятельности // Финансы. - 2009. - № 2. - С. 38-42.

11. Салина А.И. Налогообложение добычи полезных ископаемых // Налоговый вестник. - 2009. - № 8. - С. 74-75.

Поступила в редакцию 14 июня 2017 г. 
UDC 336025

DOI: $10.21779 / 2500-1930-2017-32-4-92-96$

\section{The analysis of financial and economic indicators of oil production and refining enterprises of the Russian Federation}

\section{S.V.Pimenov}

Higher school of business, Southern Federal University; Russia, 344019, Rostov-on-Don, 23-ya liniya st., 43; gartemen@mail.ru

The article analyzes the main financial and economic indicators of activity of the enterprises of oil complex. The relevance of the topic is due to the fact that the oil and gas sectors are the main suppliers of tax revenues to the Russian budget.

The dynamics of indicators of oil production and refining, the problems and prospects and the main trends of oil production and refining companies are discussed. The reflection of the complicated market situation (growth of the dollar, the increase in the tax rate on mining, lower oil prices) on the financial condition of the enterprises of oil production and refining is analysed. The author's opinion about the future plans of reforming the taxation system of oil refineries the change of the calculation formula of the severance tax, a tax on extra income) is given.

Keywords: oil, oil products, tax on mineral extraction, the tax maneuver.

Received 14 June, 2017 